\title{
NOVEL CONCEPTS IN WELD SCIENCE: ROLE OF GRADIENTS AND COMPOSITE STRUCTURE
}

\section{TECHNICAL PROGRESS REPORT}

For the Period June 1, 1990 - August 31, 1992

D.K. Matlock and D.J. Olson

Center for Welding and Joining Research Colorado School of Mines

Golden, Colorado 80401

August 31, 1992

Prepared for the U.S. Department of Energy Agreement No. DE-FG02-87ER45308 
Abstract., , . . . . . . . . . . . . . . . . 1

1.0 Introduction. . . . . . . .............. 2

1.1 Influence of Solidification................ 3

1.2 Significance of Research Effort. . . . . . . . . . . . 3

2.0 Revlew of Work Completed on Phase Transformations in

Cored Structure. . . . . . . . . . . . . . . . . . . . . . . . 4

3.0 Review of Work Completed on Weld Metal Cracking . . . . . . . . 5

3.1 Brittle Cxacking in Simulated Weld Metal. . . . ..... 6

3.2 Ductile Cracking in Simulated Weld Metal. . . . . . . . . 7

3.3 The Effects of Dynamic Compositional Gradients on the Creep Behavior of Weld Metal . . . . . . . . . . 8

3.4 Composite Weld Metal. . . . . . . . . . . . . . . . 11

4.0 References. . . . . . . . . . . . . . . . . 12

5.0 Accomplishments . . . . . . . . . . . . . . . . . . 13

5.1 Summary of Accomplishments during this Contract... . . 13

5.2 Publications from the BES Sponsored Work. . . . . . . . . 14

5.3 Theses Completed during this Contract Perlod. . . . . , . 16

5.4 Honors and Awards..................... 16

6.0 Collaborative Work. . . . . . . . . . . . . . . . . . . . 17

7.0 Research Personnel. . . . . . . . . . . . . . . . . . . . . 17 


\section{Abstract}

The effects of compositional and microstructural gradients on weld metal properties were investigated. The presence of gradients provides the primary difference between weld metal and wrought metal and the influence of gradients need to be characterized if weld metal properties and behaviors are to be modeled and analytically predicted. The effects of compositional gradients were analyzed using thermodynamic and composite models.

Brfttle and ductlie cracking behavior were investigated using both binary alloy single crystals and large grain castings and were prepared and tested as compact tension fatigue crack growth samples. In both cases the crack preferred to propagate along regions where the compostional gradients were the steepest and the data suggested that the tendency for cracking increases with magnitude of the gradient. These results add further understanding to the beneficial role of post weld heat treatments and indicate the need for weld metal modelling based on conditions and mechanfsms not common to wrought materials.

High temperature deformation of large wavelength compositonally modulated structures was investigated to understand creep behavior in weld metal. At moderate temperatures the creep behavior of cored materials was found to follow predictions based on the rule of mixtures composite analysis when the layer properties were based on the average layer compositions. At higher temperatures with the advent of dynamic mass transport the creep process is influenced by the diffusion promoted vacancy flow and the time dependent compositional gradient. The investigation has determined experimentaliy and has modelled the critical gradent which wili pronote Kirkendall volds and has reported a creep rate behavior that suggests strong structural dependence, localized stress and vacancy transport influence. 
Held metal, which is based on the design and use of metal matrix coraposite material, was also demonstrated. This novel veld metal material offers a new way to achleve properties and has numerous applications with the Increased demand for Improved propertles for weld deposits.

\subsection{INTRODUCTION}

Weldments represent complex heterogenous materlals whlch contain gradients in composition, microstructure and properties. These gradients are the primary factors which differentiate weld metal and its behavior from wrought materlals. The nature of the gradients in weld metal strongly depends on metal composition and thermal experience. The genests of weld coring depends on microsegregation and the compositional profile depends on the amount of self homogentzation during the welding thermal cycle and time and temperature of the post weld heat treatment. Analysis of the fnfluence of gradients on weld properties and behavior will allow a fundamental improvement in the abllity to predict weld metal properties.

Within the DOE-BES research program at the Colorado School of Mines, the effects of microcompositional gradients on the microstructure and properties of weld metals, both actual and simulated, have been considered in three specific studies:

(1) the characterization of cracking behavior in simulated weld metal,

(11) the characterization and modeling of local creep behavior with dynamic concentration gradients, and

(11i) an evaluation of the use of composite concepts in designing weld metal by producing weld metal consisting of a metal matrix with an Inorganic compound second phase.

In this report accomplishments which have been achleved to date during this grant period (June 1, 1990 to May 31, 1993) are reviewed in the following 
two sections. A detalled listing of speciflc accomplishments, along with a list of publications, theses, and awards which have resulted from this work are sumarlzed in section of 5.0. In each discussion the spectfic publications which were derived from the work are identifled by the "p" reference numbers from Section 5.2 .

\subsection{Influence of Solidification}

Weld metal consists of cored microstructures. On cooling through the two phase (11quid/solid) field, a compositional profile in the liquid ahead of the 1iquid/solid interface develops. The profile is controlled by solute diffusion and the magnitude of the solute partitioning coefficient, $k$, and the composition of the solute in the Ifquid adjacent to the 1Iquid/solid interface is given by $C_{0} / k$, where $c_{0}$ is the average bulk composition. As solidification in the weld pool progresses and the neighboring dendrites thicken and approach each other, the last interdentritic liquid to solidify can have a solute composition approaching $2 \mathrm{C}_{0} / \mathrm{k}$. The final weld metal compositional proflle will result fran the self homogenization of these solidification promoted interdendritic solute segregation. The weld metal is strongly influenced in this manner by the alloy composition and the weld parameters (thermal experience). The resulting microsegregation influences weld metal properifes and mechanical behavior and the influence of this chemically nonunfform material needs to be characterized and modeled to make the next major advancement to weld metal scfence (P1).

\subsection{Significance of Research Effort}

The primary difference between weld metal and wrought alloys is the microsegregation due to solidification which has major influence on the sequential phase transformations which generate the microstructural features 
that control properties. Major improvements in welding consumables and practice could be more effectively made if there were a fundamental understanding of behavior of chemically nonuniform materlal (P2, P3). The long range intended use of this research is to provide a fundamental foundation for significant improvements in our ablilty to predict weld metal properties. To achieve a basic understanding of the influence of compositional gradients, simulated weld metal has been produced by lamination of solld solutions through roll bonding and annealing and through the use of directionally solidifled binary alloy castings and single crystals. This analytical approach removes some of the complex and nonoriented features of the weld metal.

\subsection{REVIEW OF WORK COMPLETED ON PHASE TRANSFORMATIONS IN CORED STRUCTURE}

The phase stability of weld metal was a major inftiative in the prior DOE-BES welding grant (June 1, 1987 to May 31, 1990) contract and the final results have been analyzed and reported during this grant perfod ( $P 4)$. The formation of weld metal inclusions, topologlcal closed packed phases, and martensfte were all investigated (P5-P8).

Weld metal, which possesses solldification structure, consists of localized variations in alloy compositions that influence the formation of second phases. The influence of the solidification structure can be realized by consldering an element such as oxygen in ferritlc steel welds. The oxygen. concentration at solfdification of the interdendxitic liquid can be over 10,000 ppm Instead of the 300 ppm average composition determined analyticaliy from bulk chemically analyses. The locally high oxygen concentrations cause major perturbations to the interdentritic pyrochemistry, and as a result, the non-metalif inclusions axe found aligned in the interdendritic regions of the 
weld metals. Furthermore, their compositions, concentrations and size distributions are strongly influenced by these perturbations (2).

Non-metalilc inclusions affect weld metal phase transformations. The type, amount and size distribution of inclusions, if adequately controlled, can assist in the development of improved weld microstructures and properties.

A preliminary investigation has been made to better understand the interdentritic phase stability leading to inclusion formation. The pyrochemical approach to investigate weld metal inciusion formation was suggested. The relationship of coring to critical inclusion size for the nucleation of inclusions was also reported (PI).

The Influence of coring in high alloys on the topological closed phase formation has also been investigated. Ogborn (3) demonstrated that the "New Phacomp" analysis of Cleslak et al. (4) applies for the prediction of weld metal TCP formation. Carpenter et al. (P5) extended this "New Phacomp" analysis to Include the Influence of post weld heat treatment on weld metal phase stability.

Martensite formation is also Influenced by localized compositional varlations. For both the as welded and fully homogenized weld metals, self et al. (5) reported $M_{s}$ equations which can be used ovex broad compositional. ranges. These equations have already been incorporated into a major textbook on steel metallurgy. The papers on ferrite prediction in stalniess steel. weld metal $(6,7)$, which are based on the work performed with our prior BES contract, have recently been used to produce a new rso standard on ferrite prediction.

\section{O REVIEW OF WORK COMPIETED ON WELD METAL CRACKING}

The influence of compositional gradients on both brittle and ductile cracking behavior was investigated. The brittle cracking which occurs with 
minimal dislocation movement was studied using stress corrosion cracking (P8). The ductile cracking behavior was studied using the locallzed plasticlty resulting from fatigue testing ( $P 9)$. Both studies used weld simulated specimens which aligned the coring or laminated structure such that the cracks can selectively propagate through a range of compositional gradients.

\subsection{Brittle Cracking in Simulated Weld Metal}

An investigation studying bxittle cracking behavior in cored material, which was primarily performed during the last BES grant period, was finished and reported in this contract perlod. This investigation used stress corrosion cracking in a fully austenftic stainless steel casting with various homogenlzing heat treatments to investigate brittle cracking behavior (P8). These heat treatments produced a series of specimens with different compositional gradients in their cored structure.

If the controlling mechanism for stress corrosion crack growth is anodic dissolution, the crack should propagate through the localized region of least corrosion resistance (1.e. most anodic). This region is 1 ikely to have a lower content of passivating elements. In this investigation the crack was found to propagate where the chromium content had the steepest compositional gradient in the cored solidifled structure (PB). This cracking behavior is consistent with an interfactal energy-sensitive SCC model which had been modifled with the Cahn-Hilliard concepts (8) for influence of compositional gradients.

The results of this investigation ( $P 8$ ) and the use of the Cahn-H1lliard non-uniform thermodynamic concepts to explain the cracking behavior offer significant insight into other brittle cracking beheviors where compositional gradients are present, e.g. Ifquid metal embrittiement. 


\subsection{Ductile Cracking in Simulated Weld Metal}

The presence of microsegregation has been found to also affect ductile fracture ( $(P 9)$. An Investigation of fatigue crack propagation in compact tension fatigue specimens, which were spectally prepared from orfented very large grained copper-nickel castings and copper-nickel single crystals, was performed. These spectmens were slso homogenized to different degrees to produce samples with different compositional gradients.

Fatlgued specimens were analyzed with metallography, elemental microprofiling, fractography, and transmission electron microscopy, and the results showed that fatigue crack propagation preferentially followed locations with the steepest compositional gradients. The fatigue crack growth rates were also measured to determine the influence of the compositional gradients. Transmission electron microscopy indicated that size of the stacking faults in region adjacent to the crack in fatigued specimens is influenced by the compositional gradient. The stacking faults were significantiy smaller in specimens in the as-cast condition compared to samples which were fully homogenized. Limited hardness testing also indicated that plastic deformation occurs to different degrees in the as-cast single crystal specimens compared to homogenized specimens.

These preliminary results raised a number of important questions with respect to the effects of gradients on fatigue crack growth. Further research to better characterize and model the defornation mechanisms in cored material needs to be performed. One method which was suggested in the previous work is to use laminated specimens as simulated weld metal to clearly bring out the specific influences of compositional gradients. Extensive transmission electron microscopy work is required with special chemical profiling support to achieve a better characterization of the defect structure in order to 
relate this work to our mechanistic understanding of fatigue, and more speciflcally, plastic deformation.

\subsection{The Effects of Dymamic Compos ttional Gradients on the Creep Behavior of Weld Metal}

The relationship between microcompositional gradients and weld metal fallures at high temperature still remalins unclear. Recently the effects of microstructural and compositional gradients on high temperature mechanical properties of weldments have been considered in several studies. Analysis of the impression creep behavior across austenttic to ferritic steel dissimilar metal weldments showed that the minimum in creep resistance occurs in a zone adfacent to the fusion line where creep cracking has been observed in service (9). Impression creep behavior across beads in multipass low carbon steel weld metal showed that the griln refined hear affected zone exhibited lower creep resistance than either as-solidified or reheated as-solidified beads. The lower creep resistarce in weld metal. was found by these measurements but It is difficult to achleve mechanistic understanding due to the presence of complex and nonoriented compositional and microstructural gradients.

To provide a material with a simplified gradient for impression creep analysis, Lisin et al, (P10) evaluated the impression creep behavior across a roll bonded interface between coppex and a copper-zinc solid solution alloy. The observed creep rates varied significantly with position on a traverse across the interface and correlated with predictions based on a composite model which considered deformation to be concentrated to a zone below the impression creep punch.

Chol et 21 . (P11-P14) extended the composite analysis of Lisin et al. (P10) to a study of the tensile creep behavior of weld metals and laminate composites with controlled composition gradients. The effects of weld metal 
microsegregation, as altered by post-weld heat treatments, on high temperature creep properties were Investigated on Monel alloy 400 (NI-Cu alloy) weld metal (10, P14). All weld metal tensile samples were machined from single pass GTA welds and were heat treated in vacuum in the range of $600^{\circ} \mathrm{C}$ to $1000^{\circ} \mathrm{C}$ to produce samples with different composition gradients. Long-time constant load creep tests were performed at $500^{\circ} \mathrm{C}$. The steady state creep rates decreased with a decrease in the amplitudes of composition gradients. The deformation behavior of the solidified dendritic weld metal microstructure was modeled based on results obtained on laminate composites of nickel and copper. A roll bonded laminate composite with forty 20 micron thick layers of each material was chosen to simulate the continuous variations in local composition gradients existing at the cored dendrites in as-solidified weld metal. The laminates, prepared by roll bonding, were annealed to produce controlled composition gradients with dimenslons equivalent to those observed in the weld metal. With an increase in heat treatment time (i.e, a decrease in the composition gradient amplitude) the laminate composite steady state creep rates decreased and correlated directly to a model based on the rule of mixtures when the layer properties were based on the average layer compositions. This investigation was performed at a temperature where there was no apparent change in the localized compositional profile during the length of the creep test, and thus, the creep process was unaffected by interdiffusion between the layers.

To evaluate the effects of intexdiffusion during deformation on the high temperature mechanical properties of materials with dynamically unstable microcompositional gradients were considered by Wang et al. (P15, P16) in their study of the high temperature creep behavior of roll bonded laminate composites with alternating $21 \mu \mathrm{m}$ layers of nickel and $\mathrm{Ni}-\mathrm{Cu}$ solid solution 
alloys (with copper concentrations between 9 and 48 at. pct, Cu). All tests were performed on materials in the as-rolled condition. The composition couples were chosen to span the range where significant interdiffusion would occur during high temperature creep testing but would not lead to interfacial Kirkendall void formation. Creep tests were performed in the temperature range of 577 to $700^{\circ} \mathrm{C}$ at stress levels between 30 and $104 \mathrm{MPa}$. The creep curves were analyzed to determine the effects of layer composition and interdiffusion on curve shape and creep rate at a given time. The creep rates demonstrated nonlinear behaviors with composition, behavior which was dependent on the coring amplitude as measured with energy dispersive spectroscopy (EDS). The deformation behavior can not be described by anelyses based on a simple zule of mixtures. Observed deviations from conventional tehavior which result from changes in the microcompositional gradients were considered in conjunction with an analysis of creep mechanisms. When the results were analyzed in terms of classical power law creep rate law and compared results with the literature, the observed changes in $n$ and $Q$ suggest various controlling mechanisms.

The apparent controlling mechanism depends on the microsegregation amplitude and wavelength, environmental temperature, and the applied stress. At low stress and high temperatuxe $\left(e \cdot g .700^{\circ} \mathrm{C}\right)$, creep is dominated by thermally activated deformation or short-circuit diffusion. At moderate stresses and medium temperatures (e.g. 627 to $664^{\circ} \mathrm{C}$ ), creep is apparently dominated by lattice diffusion assisted climb. At high applied stresses and low temperatures $\left(e .8 .577^{\circ} \mathrm{C}\right)$, creep appears to be dominated by the effects of athermal excess vacancies to enhance atomic mobility. Further research with specifically designed experiments to verify the suggested mechanistic creep behavior needs to be performed. 


\subsection{Composite Weld Deposit}

Au Investigation was performed to study the fundamentals associated with the production of particulate metal matrlx composite weld deposits in which the weld deposit would have a high volune fraction of unfformly distributed Insoluble ceramic or refractory metal particles (P17), In this investigation weld deposits with austanitic stalniess steel (AISI 310) base metal were produced and both gas metal arc and gas tungsten arc welding procedures were used to study the effects of the weldirig process on particle transfer and renovery. The effects of density and size of the pertlculates were determined using different powder materials. Tungsten (coated and uncoated), tungsten carbide, nioblum carbide and titanium carblde ware selected sor powder materials as they represented particulate materlols with densfties which were Less than, equal to, or greater than the stalnless steel matrix. Varlous particle size distributions were investigated ranglng around an average size from 0.5 to 250 microns. This comblnation of materials and sizes allowed flulo flow and solidffication particle entrapment models which consider the particle distribution in the solld matrix to be evaluated. Processing parameters for acceptable solidiffcation of the weld deposits with second phase particulates were determined.

Weld deposits for each powder type and for both gas metal arc and gas tungsten arc were amalyzed. The results demonstrated that partfeulate metal. matrix composite weld deposits can be made and that the particlos can be tranaterred through the arc into the weld pool. Particle dispersions can be controlied with proper selection of powder materith. The cxterion for optinum powder material include particle size, type, density and composition, The tendency for particle suspersion in the l1quid weld pool was modeled using both fluld flow calculations and andytical prediction for the critlcal condition: where the particle is elther entrapped into the sold, or is dragged 
by the solid/1fquid interface during solidification. These calculations satisfactorliy predicted the behavior of a specifle type and size of particle in the weld pool. Titanium carbide particulates with an average size of 1 micron were found to produce well distributed particles in the weld deposits and improved material properties. Thus, weld deposits can be engineered by using composite material design concepts.

An epplication for this kind of weld deposits would be in welded assemblies for high temperature service, such as components of heat exchangers and power plarts. The creep resistance can be significantly improved by a homogeneous dispersion of second phase particles which can serve as effective cbstacles to the dislocation motion incrasing the creep resistance of the metal. When subjected to an external load, the particles tend also to carry a higher stress, thereby reducing the stress level experienced by the matrix. Thus, the creep resistance of particle relnforced alloys is inproved by these two mechanisms: bypassing of the particles by dislocations and reduction of creep rate associated with the stress distribution.

\subsection{REYERENCES}

1. D.L. Olson, S. LIU, and O.R. Edwards, "Role of Solfdification of USLA Steel Veld Metal Chemistry", Proc. of Meterials Weldability Symposium, TMS, Detrolt, MI, October (1990), TMS-AIKE, Warxendale, PA (1991).

2. R.H. Frost, D.L. Olson, and $S$, LIu, "Influence of Solidification on Inclusion Formation in Welds", Proc. 3rd Int. Conf. on Trends in Welding Research, Gatlinburg, TN, June 1992, ASM, Materlals Park, OH (1992).

3. J.S. Ogborn, "An Examination of the Solidffication Behavior and Microstructural Evolution in N1ckel Base Alloys", CSM Thesis T-3625 (1988).

4. M.J. Cleslak, G.A. Knorovsky, IN.J. Heedley, and A.D. Romig, Jr., "The Use of New PHACOMP in Understanding the Solidification Microstructure of Nickel Base Alloy Weld Metal", Met. Trans., 17A (12), pp. 2107-2115 (1986). 
5. J.A. Self, B.F. Carpenter, D.L. Olson, and D.K. Matlock, "Phase Transformation and Alloy Stability in Fe-Hn-NI-Cr-Al Weld Metal", Alternate Alloying for Environmental Resistance, pp. 37-45, TMS-ATME, Warrendale, PA (1987).

6. T.A. Slewert, C.N. McCowan, and D.L. O1son, "Ferrite Number Prediction to $100 \mathrm{FN}$ in Stainless Steel Weld Metal", Welding Journal, 67 (12), Pp. $289 \mathrm{~s}-298 \mathrm{~s}(1.988)$.

7. C.N. McCowan, T.A. Siewert, and D.L. Olson, "Stalnless Steel Held Metal: Prediction of Ferrite Content", Welding Research Council Bulletin 342, WRC, N.Y., N.Y., April, 1989.

8. J.W. Cahn, and J.E. Hilliard, J. Chem. Phys., 28 (2), pp. 258-267 (1958).

9. W.S. Gibbs, S.H. Wang, D.K. Matlock, and D.L. O1son, "High Temperature Impression Creep Testing of Weldments", Welding Journal, vol. 64, No. 6, 1985, pp. $153 \mathrm{~s}-158 \mathrm{~s}$.

10. I.D. Chol, D.K. Matlock, and D.I. Olson, "The Influence of Composition Gradients on Tenstle Properties of Weld Metal", Scripta Metaliurgica, vol, 22, 1988, pp. 1563-1568.

\section{$\underline{5.0}$ ACCOMPLISHMENTS}

\subsection{Sunmary of Accomplishments During Th1s Contract}

1. Laminate composites of pure nickel and $\mathrm{NI}$ - Cu solfd solutions

alloys have been fabricated and shown to exhtbit predicted properties with respect to porosity formation during high temperature.

2. Creep data in laminate composites have been obtained as a function as a function of stress and temperature and have shown to depend on the dynamic concentration gradients which develop during creep. Observed changes in the stress exponent and activation energy for creep are interpreted to reflect changes in controlling deformation mechanisms as a result of interdiffusion.

3. Techniques for evaluating the fine interlayer microstructures in laminate composites have been developed and the resulting dislocation structures in crept specinens have been evaluated in a 
study performed jointly with the transmission electron microscopy groups at the National Renewable Resources Laboratory and Oak Ridge National Laboratory.

4. Observed decreases in the resistance to high temperature fracture with an increase in layer thickness in laminate composites were interpreted to reflect the effects of interfactal stress redistribution and the wavelength dependence of interdiffusion during creep.

5. The basics of an FEM analysis of creep in laminate composites have been Identifled, and an initlal analysis with NIKE.2D has been completed. An analysis with a viscoplasticity FEM model has been initiated.

6. Fatique cracks propagate through reglons of steep compositional gradients in cored material. Fatigue cracks have been characterized in both directional solidified copper-nickel castings and copper-nickel single crystals.

7. The concept of using metal matrix composite weld deposits as a method to design advanced weldments was demonstrated. The physical conditions to achleve a high volume fraction of second phase with a proper particle distrlbution was identified. Fluid mechanical and solidification modeling was performed to assist in the selection of powder materials which would guarantee excellent particle distribution in the MMC weld deposit.

\subsection{Publications from the BES Sponsored Work}

P1. D.I. Olson and D.K. Matlock, "Compositlonal Gradient Effects on Weldment Properties", in Weldabillty of Materials, ed. by R.A. Patterson and K.W. Mahin, ASM, Materials Park, OH, 1990, pP. 49-55. 
P2. D.L.01son, "The Fundanentals of Welding Consumables", Proc, Gatlinburg Intern. Conf. on "Recent Trends in Welding Research", May 14-18,1989, pp 553-562, ASM, Materials Park, Oh. (1990).

P3. D.L. Olson and T. A. Slewert, "Present Consumable Technology Advances into the 21st Century", Welding Journal 69(11), 37-40 (1990).

P4. T. A. Slewert, C. N. McCowen, and D. L. O1son, "Ferrite Number Prediction for Stainless Steel Welds", Ferrous Alloy Weldments, Key Eng. Mats., Vol. 67-70, pp149-166, Trans. Pub1., Zurich, Switzerland (1992).

P5. B. F. Carpenter, D. I, Olson, D. K. Matlock and M. J. Cleslak, "Phase Stability of Fe-Al-Cr-N1 Weld Metal", Mat. Scl, and Engr., Al47, pp1$8,(1991)$.

P6. D.L. Olson and D.K. Matlock, "Weld Metal Phase Stabllity", In The Metal Sclence of Jolning, ed. by M.J. Gieslak, J. Perepezko, S. Kang, and M.E. Glicksman, TMS, Warrendale, PA, 1992, pp. 135-139.

P7. D. L. Olson, G. R. Edwards, S. LIu and D. K. Matlock, "Non-Equilibrium Behavior of Weld Meld", IIW Document IX-1685-92, pp 1-49, American Counc1l, AWS, Mlami, F1. (1992).

P8. G. L. Berry, D. L. 01son, and D. K. Matlock, "Influence of Microcompositional Gradients on Stress Corrosion Crack Propagation". Mat. Sc1. and Engr. A148, pp 1-6 (1991).

P9. A. Wahid, D. L. Olson, D. K. Matlock and J. J. Kelly, "Role of Compositional Gradients in Environmentally Promoted Weld Cracking", Prcc, of ASM "Heat Materials Conference", pp 447-452, ASM, Materials Park, Oh. (1991).

P10. M. A. Lisin, I. D. Choi, D. K. Matiock, and D. L. O1son, "A Composite Modeling Analysis of Creep Testing on Heterogeneous Materials", Welding Journal 69(4), 159s-165s (1990).

P11. I. D. Cho1, D. K. Matlock, and D. L. Olson, "Creep Behavior of Nickel Copper Laminate Composites with Controlled Composition Gradients", Met. Trans. 21A(9), 2513-2520 (1990).

P12. I. D. Choi, D. X. Matlock, and D. L. Olson, "Communication: Creep Behavior of Nickel-Copper Solid Solution Alloys Below $0.55 \mathrm{Tm}$ ", Met. Trans. 21A(9), 2601-2604 (1990).

P13. I. D. Choi, D. K. Matlock and D. L. Olson, "An Analysis of Diffusion Porosity in Copper-Nickel Composite", Mat. Sc1. and Engr. A12.4, 115-118 (1990)

P14. L. D. Chol, D. K. Matlock, and D. L. Olson, "Influence of Composition Gradients on Weld Metal Creep Behavjor: An Analysis Based on Laminate Proc. Gatlinbuxg International Conference on "Recent Trends in Welding Research", May 14-18, 1989, pp 787-792, ASM, Metals Park, Oh., (1990). 
P15. S. H. Wang, D. K. Matlock, and D. L. Olson, "High Temperature

Deformation and Fracture Behavior of Laminate Composite: The Importance of Interdiffusion During Creep", Scripta Met, and Mat., 27, pp. 35-40 (1992).

P16. S. H. Wang, D. K. Matlock, and D. L. Olson, "Physical Simulation for the Creep Behavior of Solidifled Weld Metal", Presearch, proc. 3rd Intern. Conf. on Trends in Trends in Welding Research, June 1-5, 1992, Gatlinburg, Tn, ASM, Materials Park, Oh. (1992).

P17. E. I. Xivineva, D. L. Olson, and D. K. Matlock, "Particulate Metal Matrix Composite as a Weld Deposit", to be submitted to Welding Journal, (1992).

P18. M. Holt, D. L. Olson, and C. E. Cross, "Interfacial Tension Driven Fluid Flow Model for Hot Cracking", Scripta Met. et Mat., 26, pp 1119 1124 (1992).

P19. D. D. Kautz, D. L. 01so:, P. Burgardt, G. R. Edwards, "A Characterization of Pulsed Electron Beam Welding Parameters". Welding Journal 70(4), 100s-105s (1991).

\section{3 Theses Completed during this Contract Period}

T1. Clay L. Taylor, (1991), M.S. Thesis T-4060, "The Effect of Weldability of Alloy JBK-75 with various Filler Hetal Wire Additions".

T2. Esa I. Kivineva, (1991.), M.S. Thesis T-4108, "Particulate Metal Matrix Composites as a Weld Deposit".

T3. A. Wahid, (1992), Ph. D. Thesis T-4241, Cracking Behavior of Chemically Nonhomogenized Alloys".

T4. S. H. Wang, (1992), Ph. D. Thesis T-4250, Physical Simulation of the Creep Behavior of a System with Dynamic Concentration Gradients".

\subsection{Honors and Awards}

A1. Chaxles H. Jennings Award, AWS, (1991). Award was made to M.A. LIs In, I.D. Chol., D. K . Matlock and D.I. Olson for the paper entiltled "A Composite Modeling Analysis of Impression Creep Testing on Heterogeneous Materlals". This paper was a product of this DOE-BES research program.

A2. Lincoln Award, AWS, (1992), Award was made to D.L. 01son of h1s contributions to welding research. 


\subsection{COLLABORATIVE WORK}

The Colorado School of Mines is performing cooperative research with the following federal facilitles: (a) Sandia National Laboratory (Albuquerque, N.M.), on phase stability calculations and analysis; (b) Oak Ridge National Laboratory, on special electron microscopy and analysis; and National Renewable Resources Laboratory, on special electron microscopy. CSM also hosted the BES welding collaborators meeting, October, 199.1.

\subsection{RESEARCH PERSONNEL}

David K. Matlock Co-Principal Investigator

David L. O1son Co-Principal Investigator
A. Wahid
Ph.D. Graduate Student (Completed June 1992)
S.H. Wang
Ph.D. Graduate Student (Completed Aug 1992)
E. Kivineva
M.S. Graduate Student (Completed September 1991)
Clay Taylor
M.S. Graduate Student (Completed May 1991)
Douglas Wynman
Ph.D. Graduate Student
Jodee Varney
Ph.D. Graduate Student 

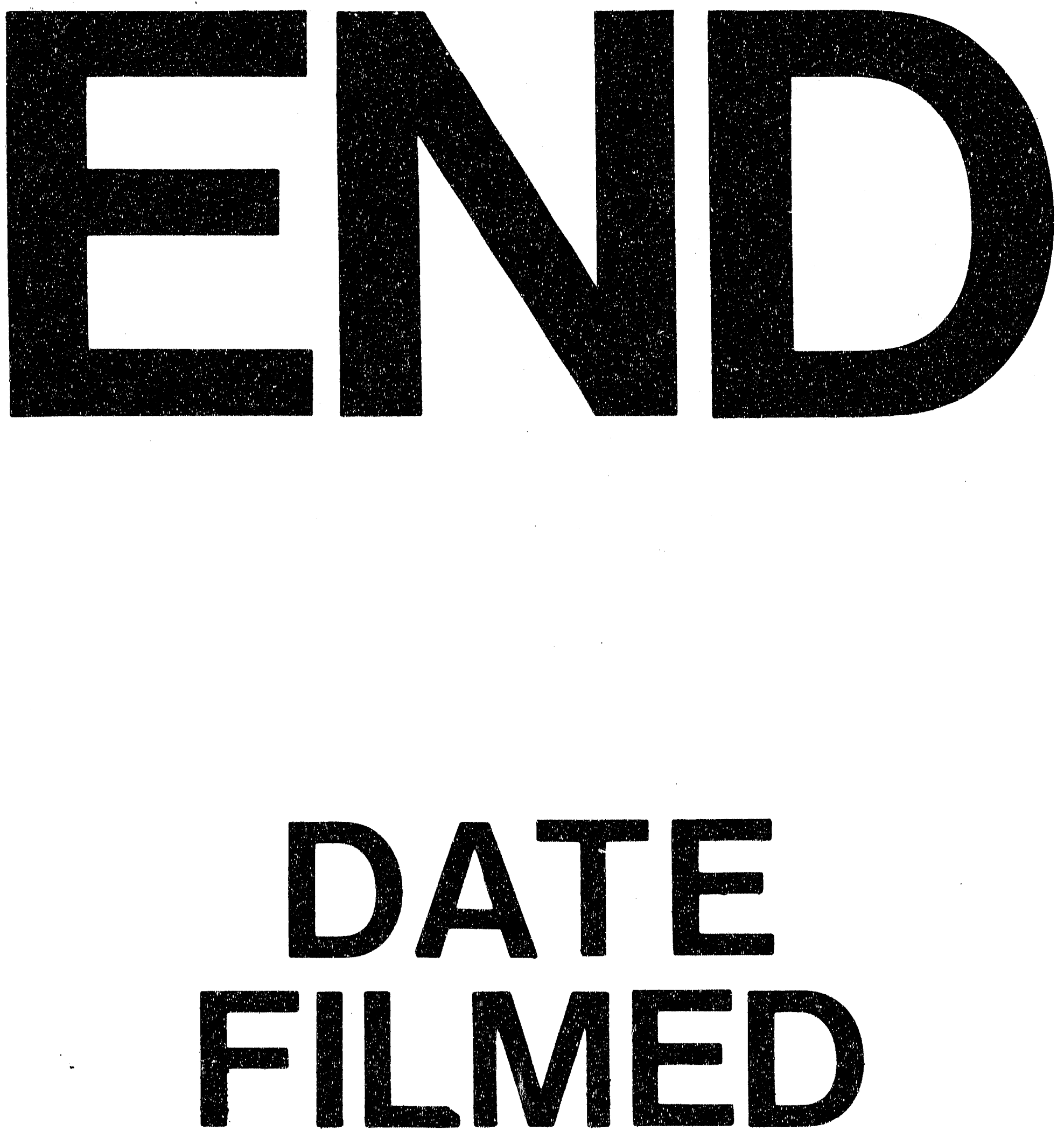

1

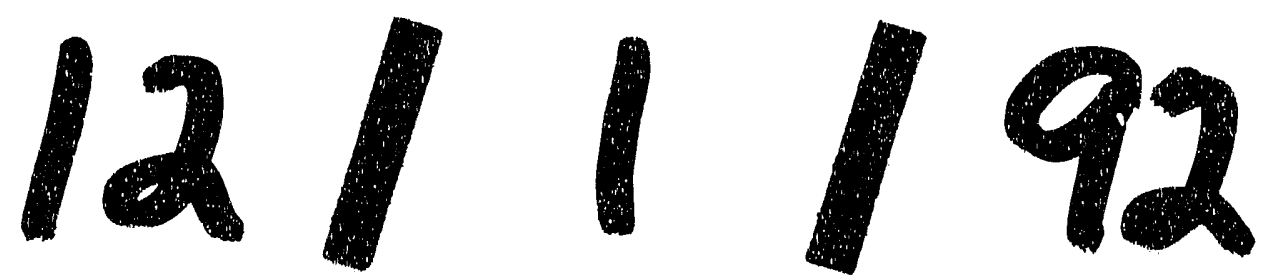


